\title{
Researchon Case Teaching in the Basic Course of Law
}

\author{
Gao Le $\mathrm{La}^{1 \mathrm{a}}$ \\ Jilin Agricultural University, Changchun, China \\ aemail: ruoyinle2001@163.com
}

Keywords:Case Method; Basic Law Course; Application

\begin{abstract}
Case method focuses on the cultivation of student analytical ability and critical spiritand in law basic coursethe use of case method is conducive to developing and enhancing the legal awareness and concepts of university students. The student learning interest and the teaching effectiveness of basic law course can be improved by means of the case method with such four closely related links as the compiling of case selectionthe case displaythe case analysis and discussionand the case summarized evaluation. In the implementation of case methodthe teachers should make a good pre- class planning good guidance in class and a good after- school evaluation.
\end{abstract}

\section{Introduction}

Case teaching method is reproduced the real life events by teachers [1]. Let the students read, analyze and look for the best solution to solve practical problems. The use of case teaching method in the teaching of the basic course of law is the use of specific cases to analyze the basic legal concepts and principles [2]. In the classroom, not only teachers can ask students, but also allow students to ask questions or interrupt the teacher's talk. This teaching method is training students' professional skills and independent thinking ability to play the enthusiasm of the students, so students can master a wide range of legal knowledge and rules [3][4].

The teacher transforms the traditional knowledge into the knowledge provider. The teacher should not only advocate the pluralism of the subject and the diversity of views and allow the students to question the teacher in the course of teaching.

Teachers are the interpreters of the law and guides to class discussions. Teachers should have a solid theoretical knowledge and skilled teaching skills. Teachers must also have the concept of service and attitude of students. The students with different cultural foundation can be guided in accordance with their aptitude.

The students change from passive recipients of knowledge into active seeker of knowledge. Teachers and students are no longer the relationship between the subject and the object, but an equal relationship between the main body and the main body in teaching. Teachers should respect students, understand students and treat students equally.

\section{The application of case teaching method in the basic course of law}

The teacher should use the example of the law and select cases and put forward problems for mobilizing the students to think independently in the teaching of legal basis. The author combines the characteristics and learning rules of non-law majors and then summarizes the application mode of case teaching method in the following links.

Case is used to reveal the legal principle and inspire students to think, so as to guide students to learn and then develop their learning ability. Therefore, selection of good case is the smooth implementation of case teaching. But cases in the teaching of basic law are not used the more the 
better and chosen at random. Teachers select case should be on teaching knowledge and strive to make cited examples and knowledge to organic combination.

The way of case introduction usually has four kinds of ways of oral, written, multimedia and real person. Generally more simple cases can be spoken to the students. More complex cases should be given to the students in writing before the class, the students can Preview. Teachers can also use the multimedia image to show the cases or let some students to demonstrate the cases [6]. In this part, teachers should pay attention to the combination of different cases and legal principles. The author believes that the following combination of the form is more feasible.

First show case after the analysis of the principle. Teachers explain the cases, and then let the students read and analyze the cases.Finally,the students summed up the relevant legal principles. This method is most commonly used in the case teaching of the basic course of law.

First explain the principle after the case. Teachers first explain the legal principle, and then produce a case. This way can strengthen and consolidate students' learning. This method is often used to assist the learning of the lesser degree of legal knowledge.

Explain the case and the principle of synchronization together. Teachers can analyze the cases According to the legal principle knowledge when displaying the case. The relevant legal principle will be analyzed and inferred. This method is mainly applied to the teaching of the complex legal principle.

This is the core of the case teaching link. In this part, teachers should make clear the rules of case discussion to ensure that the discussion can be carried out in an orderly manner. The author believes that the case discussion mainly includes the following steps:

Step 1:A clear discussion of rules. The teacher should arrange the discussion time, the order of discussion, the time of speech and the order of speech and so on, and then the relevant rules need to be announced to the students before the class.

Step 2:A panel discussion. The teacher may divide the students into several discussion groups in the form of temporary or voluntary groups. Each group is appointed or elected to the organizer. The team put forward the problem of the case, combined with the legal principle of the school to discuss. In a shorter time with a consistent view of the cost of the group, the group's point of view is organized into a brief report.

Step3: Group representatives read the report. The time to read the discussion report is controlled at 3- 5 minutes. The content of the report is clear and full. The students who read the report must also have a clear and fluent language. When one group representatives speak, the other group of students put the group's point of view and argument in a timely manner to prepare for the next step in the discussion between the groups.

Step 4: Discussions between the various groups. All groups can ask questions and answers on their respective views and arguments after reading the discussion report. Due to the complexity of the collective discussion, teachers need to effectively control and properly guide the students to discuss the situation. Teachers should use encouragement and prompt to prevent the discussion from deadlock. Teachers should try to record the content of the students' questions and comments and discuss the situation in order to prepare a case to review the evaluation of the use of links.

The teacher can make a summary and comment on the practice of the case teaching after the end of the discussion of the case. The teacher needs to evaluate the students from the discussion of ideas, analysis methods, and solutions and so on. The teacher should encourage students to think and debate and to guide students to conduct in-depth thinking about the issues involved in the case. 


\section{Matters needing attention in case teaching method}

Pay attention to the teaching plan before class. In order to make the case teaching method better serve for the teaching of the basic course of law, teachers must put a lot of time and energy into the class and make a specific organization and implementation plan for each teaching case. The author holds the view that the organization of case teaching implementation plan should include the type of case, source case, case display mode, the contents of the case introduction, case selection and choose perspective, through the case leads to the legal principle and the important points of knowledge, to students issued time case, case discussion site arrangement, classroom discussion to discuss issues in the design of case, specific procedures to organize and case discussion of rules, teachers personal point of view, case discussion that may arise in the process of the question and the countermeasure, course score evaluation standard.

Organize and guide the discussion in class. A successful case teaching can't be separated from a good teaching Organizer. The teacher must follow the teaching rules of case teaching to cultivate students' thinking and analytical ability In case teaching, and then Guide class discussion According to the different content of the case, teaching scene and teaching object. The Teacher in the classroom should create an atmosphere conducive to mutual learning and research to mobilize the students to discuss the atmosphere. Students' creativity and individuality are fully played in this class. The Teacher need to be good at handling such as ice, radical rhetoric and other special situations, so that the case teaching to achieve the desired purpose and received good results.

Establish the evaluation mechanism after class.The purpose of case teaching is to cultivate students' ability of analysis, debate, critical thinking, group and interpersonal relationships, communication skills and expression ability. Through analyzing and interpreting the real legal events, the Teacher cultivates students' ability to think, analyze and solve problems independently. The result of case teaching is different from the traditional method. It mainly inspects the students' thinking.The Teacher should overcome the subjective and arbitrary nature of the students when students are judged according to the objectives and characteristics of the teaching. The Teacher examines students thinking is to choose whether accurate, analysis of the steps of the case is appropriate, can seize the essence of the problem and the key to the use of the method of thinking is skilled and so on. This can achieve a comprehensive evaluation of students' comprehensive learning ability and learning level. Scientific evaluation mechanism is an important way to evaluate the effectiveness of the case teaching, but also an indispensable part of the case teaching. The teachers and the teaching management department should pay enough attention to it.

\section{Conclusion}

The application of case teaching method in the basic course of law is a kind of effective teaching method. It can become boring for vivid and greatly improve the students' learning interest. After the implementation of case teaching, students change from passive learning to active learning which is the main body of classroom teaching.

\section{References}

[1] Zhao T N, Wang H W, Huai en B U, et al. Practice and research of case teaching method in teaching of preventive medicine[J]. China Higher Medical Education, 2009.

[2] Haizhen W U, Jiang J F. Applying Relating Case Teaching Method to Visual Basic Programming [J]. Computer Education,2009. 
[3] LU Lai zhi, SU Ying. Case Teaching Method In The Application of Computer Networks[J]. Science \& Technology Information, 2009.

[4]Yao S. Use of the Case Teaching Method to Improve the Efficiency of Classroom Teaching[J]. Guide of Science \& Education, 2014.

[5]YE Shu-ling, ZHANG Yu-min.The Application of Legal Cases to the Teaching of the Basic Course of Law[J].Journal of Xian University of Architecture \& Technology, 2005.

[6]Zhang Z L. An Approach to the Teaching Method of Simulated Court Applied in the Basic Course of Law[J]. Journal of Nanjing University of Posts \& Telecommunications, 2004. 